\title{
PENGARUH PEMANASAN, TINGKAT KEASAMAN (pH) DAN KONSENTRASI GARAM TERHADAP STABILITAS ANTIBAKTERI EKSTRAK ETANOL KULIT KAYU AKWAY (Drimys piperita Hook.f.)
}

\section{Effect of Heating, Acidity Levels ( $p H$ ) and Salt Concentrations on Stability of Ethanol Extracts of Akway (Drimys piperita Hook.f.) Barks}

\author{
Gino Nemesio Cepeda *1), Meike Meilan Lisangan 1), Isak Silamba 1), \\ Nitia Nilawati 2), Eka Syartika 2) \\ 1) Jurusan Teknologi Pertanian Fakultas Teknologi Pertanian Universitas Papua \\ 2) Alumni Jurusan Teknologi Pertanian Fakultas Teknologi Pertanian Universitas Papua \\ Jl. Gunung Salju Amban Manokwari Kode Pos 98314 \\ *Email: ginocepeda.gc@gmail.com
}

\begin{abstract}
Akway (Drimys piperita Hook.f.) is a woody, evergreen and aromatic plant that belongs to family Winteraceae. This plant is used by Sougb tribe lived in Sururey village, District of Anggi, to enhance the vitality of body. The objectives of the research were to determine antimicrobial stability of akway bark extracts influenced by heating time of $100^{\circ} \mathrm{C}$, levels of acidity $(\mathrm{pH})$ and salt contents. Antimicrobial assays were done by using agar well diffusion method against four species of bacteria, i.e. Escherichia coli ATCC25922, Bacillus cereus ATCC10876, Pseudomonas aeruginosa ATCC27853 and Staphylococcus aureus ATCC25923. The results showed that ethanolic extracts of akway bark only inhibited growth of B. cereus and S. aureus with minimum inhibitory concentration 0,99\% and 0,89\%. The levels of concentration and acidity of ethanol extracts influenced the antimicrobial capacity of extracts, whereas heating time on $100^{\circ} \mathrm{C}$ for 25 minutes and salt contents up to $5 \%$ of extract solution did not influence the antimicrobial stability of akway bark extracts.
\end{abstract}

Key words: akway, extracts, antimicrobe, $p H$, heating, salt

\section{ABSTRAK}

Akway (Drimys piperita Hook.f.) adalah tumbuhan berkayu, aromatik dan hijau sepanjang tahun dan tergolong dalam suku winteraceae. Tumbuhan ini digunakan oleh Suku Sougb yang bermukim di desa Sururey Distrik Anggi, untuk mengobati malaria dan meningkatkan vitalitas tubuh. Tujuan dari penelitian ini adalah untuk menentukan stabilitas antimikroba ekstrak kulit kayu akway pada waktu pemanasan ekstrak pada $100^{\circ} \mathrm{C}$, tingkat keasaman $(\mathrm{pH})$ dan kandungan garam. Pengujian antimikroba dilakukan dengan menggunakan metode difusi agar terhadap empat spesies bakteri yaitu Escherichia coli ATCC25922, Bacillus cereus ATCC10876, Pseudomonas aeruginosa ATCC27853 and Staphylococcus aureus ATCC25923. Hasil menunjukkan bahwa ekstrak etanol kulit kayu akway hanya dapat menghambat bakteri Bacillus cereus dan Staphylococcus aureus dengan konsentrasi hambat minimum masing-masing adalah $0,99 \%$ dan $0,89 \%$. Tingkat konsentrasi dan keasaman (pH) mempengaruhi kapasitas antimikroba ekstrak etanol kulit kayu akway. Sedangkan perlakuan pemanasan pada suhu $100^{\circ} \mathrm{C}$ dengan lama pemanasan sampai dengan 25 menit dan penambahan garam $\mathrm{NaCl}$ sampai konsentrasi $5 \%$ tidak berpengaruh pada stabilitas antimikroba ekstrak etanol kulit kayu akway.

Kata kunci: akway, ekstrak, antimikroba, pH, pemanasan, garam

\section{PENDAHULUAN}

Akway (Drimys piperita Hook.f.) merupakan tumbuhan endemik Papua, yang termasuk dalam tumbuhan berkayu, berdaun hijau aromatik dan dikelompokkan ke dalam suku 
Winteraceae (Stevens, 2017). Akway digunakan sebagai tumbuhan obat tradisional etnis Sougb di Distrik Sururey Papua untuk mengobati malaria dan meningkatkan daya tahan tubuh ketika melakukan pekerjaan berat (Syakir dkk., 2011).

Beberapa penelitian tentang kandungan senyawa fitokimia akway dan daya antimikrobanya telah dilakukan. Cepeda dkk. (2010) melaporkan bahwa ekstrak metanol kulit kayu D. piperita mengandung kelompok senyawa fenolik (flavonoid dan tanin), terpenoid, saponin dan alkaloid. Akway juga dilaporkan mengandung sejumlah senyawa yang memiliki aktivitas antimikroba dalam komponen minyak atsirinya. Komposisi utama penyusun minyak atsiri daun akway adalah senyawa $\alpha$-pinen, $\beta$-pinen, linalool dan nerolidol (Cepeda et al., 2011a), sedangkan pada minyak atsiri kulit kayunya tersusun dari $\alpha$-pinen, $\beta$-pinen dan 4-terpineol (Cepeda et al., 2011 b). Senyawa-senyawa seperti $\alpha$-pinen, $\beta$-pinen, terpeniol telah dilaporkan merupakan senyawa-senyawa yang memiliki aktivitas antimikroba yang kuat (Da Silva et al., 2012; Wang et al., 2012).

Ekstrak etanol dari berbagai sumber tumbuhan dilaporkan dapat menghambat pertumbuhan berbagai spesies bakteri in vitro. Cepeda et al. (2012) melaporkan, bahwa ekstrak etanol sereh dapat menghambat pertumbuhan dan produksi toksin Escherichia coli verotoksigenik. Ekstrak etanol daun Taraxacum mongolicum memiliki aktivitas antibakteri yang kuat terhadap Pseudomonas aeruginosa dan Bacillus subtilis (Qiao \& Sun, 2014), sedangkan ekstrak etanol Zingiber officinale efektif menghambat pertumbuhan Staphylococcus aureus dan Enterococcus faecalis (Grace et al., 2017).

Beberapa penelitian melaporkan bahwa perlakuan panas, $\mathrm{pH}$ dan konsentrasi garam sangat berpengaruh terhadap aktivitas antimikroba ekstrak. Ginovyan (2017) melaporkan bahwa pemanasan ekstrak pada suhu $60-121^{\circ} \mathrm{C}$ selama 30 dan 60 menit berpengaruh nyata terhadap aktivitas antimikroba ekstrak Agrimonia eupatoria. Aktivitas antimikroba ekstrak daun Carica papaya meningkat dengan menurunnya pH (Romasi et al., 2011). Konsentrasi garam sampai dengan $10 \%$ cenderung meningkatkan aktivitas antibakteri ekstrak Nicolaia speciosa (Naufalin \& Rukmini, 2018). Tujuan penelitian ini adalah untuk mengetahui aktivitas antimikroba ekstrak etanol kulit kayu akway terhadap bakteri-bakteri patogen penyebab penyakit dan untuk mengetahui pengaruh perlakuan panas, tingkat keasaman $(\mathrm{pH})$ dan konsentrasi garam $\mathrm{NaCl}$ terhadap stabilitas ekstrak kulit kayu akway.

\section{METODE}

\section{Tempat dan Waktu}

Penelitian ini dilaksanakan di Laboratorium Teknologi Pertanian Universitas Papua Manokwari. Penelitian ini dilaksanakan bulan Maret sampai Agustus 2017.

\section{Persiapan Bahan}

Kulit kayu akway yang digunakan dalam penelitian ini berasal dari Distrik Anggi Kabupaten Pegunungan Arfak Papua Barat. Kulit kayu diperoleh dari tumbuhan akway dengan diameter batang utama $\pm 8-10 \mathrm{~cm}$. Kulit kayu yang diperoleh dari batang utama dikeringanginkan pada suhu ruang selama kurang lebih 5-7 hari sampai kulit kayu menjadi mudah hancur. Kulit kayu yang sudah kering digiling dan diayak dengan ukuran 40 mesh. Bubuk yang diperoleh dikemas dalam kemasan plastik polietilen kapasitas $1 \mathrm{~kg}$.

\section{Ekstraksi}

Proses ekstraksi dengan pelarut etanol absolut dilakukan menggunakan metode maserasi. Perbandingan bubuk kulit kayu akway dan pelarut etanol adalah 1:4 (100 gram bubuk kulit kayu akway ditambahkan $400 \mathrm{ml}$ etanol). Proses ekstraksi dilakukan pada suhu ruang selama 72 jam dengan pengadukan menggunakan shaker incubator. Setelah proses maserasi selesai, 
campuran disaring dengan kertas saring Whattman no. 1 menggunakan pompa vakum. Larutan hasil penyaringan diuapkan pelarutnya menggunakan rotary evaporator Eyela N1000 pada suhu $40^{\circ} \mathrm{C}$ dengan kecepatan $60 \mathrm{rpm}$ sampai ekstrak menjadi kental. Ekstrak yang diperoleh dilakukan penguapan sisa pelarut dalam refrigerator sampai diperoleh ekstrak kental. Ekstrak hasil penguapan, disimpan dalam botol untuk digunakan dalam pengujian.

\section{Persiapan Kultur Bakteri}

Kultur bakteri uji yang digunakan dalam penelitian ini adalah Escherichia coli ATCC25922, Bacillus cereus ATCC10876, Pseudomonas aeruginosa ATCC27853 dan Staphylococcus aureus ATCC25923. Vial isolat kultur bakteri uji dibuka secara aseptik, kemudian ditambahkan nutrient broth (NB) sebanyak $1 \mathrm{ml}$ dan diaduk hingga tercampur sempurna menggunakan vorteks. Campuran kultur dan medium NB dipipet dan dipindahkan dalam tabung reaksi yang telah berisi $10 \mathrm{ml} \mathrm{NB}$ dan divorteks. Kultur diinkubasi pada suhu $37^{\circ} \mathrm{C}$ selama 24 jam. Kultur yang telah tumbuh dalam medium NB, diinokulasi pada permukaan medium agar miring nutrient agar (NA) dan diinkubasi pada suhu $37^{\circ} \mathrm{C}$ selama 24 jam. Setelah terlihat pertumbuhan bakteri pada agar miring, kultur bakteri tersebut disimpan pada suhu kamar untuk digunakan dalam pengujian.

\section{Pengujian Daya Hambat pada Beberapa Tingkat Konsentrasi Ekstrak}

Pengujian daya hambat ekstrak etanol kulit kayu akway dilakukan dengan metode agar well diffusion (Balouiri et al., 2016). Sebanyak $500 \mu \mathrm{l}$ kultur bakteri uji $\left(10^{7} \mathrm{CFU} / \mathrm{ml}\right)$, yang telah ditumbuhkan dalam medium NB pada suhu $37^{\circ} \mathrm{C}$ selama 20 jam, disebarkan merata pada permukaan medium NA steril yang telah membeku dalam cawan petri. Kemudian pada media NA yang sudah membeku dibuat sumur dengan ukuran diameter $6 \mathrm{~mm}$ menggunakan tips. Masing-masing sumur dimasukkan ekstrak sebanyak $60 \mu \mathrm{l}$ dengan perlakuan konsentrasi 0 (pelarut), 5, 10, 15, 20, dan 25\% (b/v), dengan kontrol positif penisilin G (10\%). Masing-masing perlakuan dilakukan dengan ulangan 2 kali. Kemudian dilakukan inkubasi pada suhu $37^{\circ} \mathrm{C}$ selama 24 jam. Setelah masa inkubasi selesai, diameter zona penghambatan (zona bening di sekitar sumur) diukur menggunakan caliper.

\section{Penentuan Konsentrasi Hambat Minimum (KHM)}

Penentuan nilai KHM dilakukan berdasarkan daya hambat ekstrak etanol pada berbagai konsentrasi menggunakan metode Bloomfield (1991), yaitu dengan membuat regresi linear antara nilai ln C (ln konsentrasi ekstrak) pada sumbu X, terhadap nilai kuadrat zona penghambatan ekstrak terhadap bakteri uji $\left(\mathrm{Z}^{2}\right)$ pada sumbu $Y$. Persamaan regresi linear $\mathrm{Y}=\mathrm{a}+$ bX yang berpotongan dengan sumbu $\mathrm{X}$, pada nilai $\mathrm{Y}=0$ adalah titik Mx (nilai ln konsentrasi). Nilai KHM adalah 0,25 x nilai konsentrasi ekstrak pada titik Mx.

\section{Aktivitas Antimikroba pada Pemanasan Suhu $100^{\circ} \mathrm{C}$.}

Sebanyak $500 \mu$ l kultur bakteri uji $\left(10^{7} \mathrm{CFU} / \mathrm{ml}\right)$, yang telah ditumbuhkan dalam medium NB pada suhu $37^{\circ} \mathrm{C}$ selama 20 jam, disebarkan merata pada permukaan medium NA yang telah membeku dalam cawan petri. Kemudian pada medium NA yang sudah membeku dibuat sumur dengan ukuran diameter $6 \mathrm{~mm}$ menggunakan tip. Masing-masing sumur dimasukkan ekstrak dengan konsentrasi $10 \%(\mathrm{~b} / \mathrm{v})$ sebanyak $60 \mu \mathrm{l}$ yang telah dipanaskan pada suhu $100^{\circ} \mathrm{C}$ selama 5, 10, 15, 20 dan 25 menit dan dibandingkan dengan kontrol (tanpa pemanasan). Masing-masing perlakuan menggunakan 2 kali ulangan, kemudian diinkubasi pada suhu $37^{\circ} \mathrm{C}$ selama 24 jam. Setelah masa inkubasi selesai, diameter zona penghambatan (zona bening di sekitar sumur) diukur menggunakan caliper (Balouiri et al., 2016).

\section{Aktivitas Antimikroba pada Beberapa Tingkat Keasaman (pH)}

Sebanyak $500 \mu \mathrm{l}$ kultur bakteri uji $\left(10^{7} \mathrm{CFU} / \mathrm{ml}\right)$, yang telah ditumbuhkan dalam medium NB pada suhu $37^{\circ} \mathrm{C}$ selama 20 jam, disebarkan merata pada permukaan medium NA yang telah 
membeku dalam cawan petri. Kemudian pada medium NA yang sudah membeku dibuat sumur dengan diameter $6 \mathrm{~mm}$. Masing-masing sumur dimasukkan ekstrak etanol dengan konsentrasi $10 \%(\mathrm{~b} / \mathrm{v})$ sebanyak $60 \mu \mathrm{l}$ dengan perlakuan tingkat keasamam ekstrak, yaitu $\mathrm{pH}$ 4, 5, 6, 7 dan 8,5. Tingkat keasaman ekstrak diatur dengan penambahan NaOH dan HCL 0,5 N. Masing-masing perlakuan menggunakan 2 kali ulangan, kemudian cawan petri diinkubasi pada suhu $37^{\circ} \mathrm{C}$ selama 24 jam. Setelah masa inkubasi selesai, diameter zona penghambatan (zona bening di sekitar sumur) diukur menggunakan caliper (Balouiri et al., 2016).

\section{Aktivitas Antimikroba pada Beberapa Tingkat Konsentrasi Garam}

Sebanyak $500 \mu \mathrm{l}$ kultur bakteri uji $\left(10^{7} \mathrm{CFU} / \mathrm{ml}\right)$, yang telah ditumbuhkan dalam medium NB pada suhu $37^{\circ} \mathrm{C}$ selama 20 jam, disebarkan merata pada permukaan medium NA yang telah membeku dalam cawan petri. Kemudian pada medium NA yang sudah membeku dibuat sumur dengan diameter $6 \mathrm{~mm}$ menggunakan tips. Masing-masing sumur dimasukkan ekstrak etanol dengan konsentrasi $10 \%(\mathrm{~b} / \mathrm{v})$ sebanyak $60 \mu \mathrm{l}$ yang mengandung garam $\mathrm{NaCl}$ masing-masing sebesar 0 (tanpa garam), 1, 2, 3, 4, dan 5\% (b/v). Masing-masing perlakuan menggunakan 2 kali ulangan, kemudian cawan petri diinkubasi pada suhu $37^{\circ} \mathrm{C}$ selama 24 jam. Setelah masa inkubasi selesai, diameter zona penghambatan (zona bening di sekitar sumur) diukur menggunakan caliper (Balouiri et al., 2016).

\section{Analisis Data}

Penelitian menggunakan Rancangan Acak Kelompok, dan data hasil pengamatan dianalisis menggunakan analisis varian. Jika hasil analisis varian menunjukkan berbeda nyata pada $\alpha-0,05$ maka dilanjutkan dengan uji beda nyata jujur (BNJ) $\alpha-0,05$.

\section{HASIL DAN PEMBAHASAN}

\section{Daya Hambat Ekstrak Etanol pada Beberapa Tingkat Konsentrasi}

Pengujian daya hambat ekstrak etanol kulit kayu akway dilakukan pada konsentrasi 0$25 \%$ (b/v). Hasil pengujian menunjukkan bahwa ekstrak etanol kulit kayu akway bersifat menghambat pertumbuhan bakteri Gram positif, yaitu bakteri B. cereus dan S. aureus tetapi tidak dapat menghambat pertumbuhan bakteri Gram negatif, yaitu E. coli dan P. aeruginosa (Tabel 1).

Tabel 1. Daya hambat ekstrak etanol kulit kayu akway

\begin{tabular}{ccccc}
\hline \multirow{2}{*}{$\begin{array}{c}\text { Konsentrasi } \\
(\%)\end{array}$} & E. coli & B. cereus & P. aeruginosa & S. aureus \\
\cline { 2 - 5 } & $8,12 \pm 0,09 \mathrm{a}$ & $8,18 \pm 0,81 \mathrm{a}$ & $8,55 \pm 0,78 \mathrm{a}$ & $8,13 \pm 0,46 \mathrm{a}$ \\
5 & - & $12,18 \pm 0,67 \mathrm{ab}$ & - & $11,03 \pm 0,39 \mathrm{ab}$ \\
10 & - & $13,13 \pm 0,18 \mathrm{ab}$ & - & $16,08 \pm 0,81 \mathrm{bc}$ \\
15 & - & $15,35 \pm 0,35 \mathrm{bc}$ & - & $19,08 \pm 0,67 \mathrm{c}$ \\
20 & - & $16,83 \pm 0,46 \mathrm{c}$ & - & $19,10 \pm 0,14 \mathrm{c}$ \\
25 & - & $19,28 \pm 0,74 \mathrm{c}$ & - & $19,30 \pm 0,28 \mathrm{c}$ \\
Penicilin G (10\%) & $34,23 \pm 2,32$ & $17,67 \pm 3,89$ & - & $58,32 \pm 3,64$ \\
\hline
\end{tabular}

Keterangan: Angka yang diikuti dengan huruf yang sama menunjukkan perlakuan tidak berbeda nyata pada BNJ-0,05.

Tabel 1. menunjukkan bahwa daya hambat ekstrak etanol kulit kayu akway terhadap pertumbuhan bakteri $B$. cereus dan $S$. aureus meningkat seiring peningkatan konsentrasi ekstrak. Hasil yang sama juga ditemukan pada ekstrak etanol umbi Curcuma longa (Singh et al., 2017), daun Andrographis paniculata (Mardiana \& Handayani, 2016) dan daun Quercus infectoria (Shariatifar et al., 2014). 
Peningkatan penghambatan ekstrak kulit kayu akway terhadap pertumbuhan bakteri sebanding dengan jumlah senyawa yang memiliki aktivitas antimikroba yang terkandung dalam ekstrak pada konsentrasi yang semakin tinggi. Menurut Seow et al., (2014), aktivitas antimikroba akan meningkat dengan meningkatnya konsentrasi senyawa aktif. Peningkatkan konsentrasi senyawa aktif dalam ekstrak akan meningkatkan laju difusi senyawa tersebut dalam medium agar sehingga diameter zona hambat semakin besar.

Pada Tabel 1. dapat dilihat bahwa ekstrak etanol kulit kayu akway tidak mampu menghambat pertumbuhan E. coli dan P. aeruginosa. Hasil penelitian yang sama juga ditemukan pada ekstrak etanol Cassia alata, Centella asiatica, Curcuma longa dan Zingiber officinale. Ekstrak etanol dari tumbuhan obat tersebut tidak dapat menghambat pertumbuhan bakteri E. coli dan $P$. Aeruginosa (Valle Jr. et al., 2015).

Ketidakmampuan ekstrak akway dalam menghambat pertumbuhan E. coli dan $P$. aeruginosa, diduga disebabkan kedua bakteri ini merupakan kelompok bakteri Gram negatif yang memiliki lapisan membran terluar (outer membrane) yang dapat mencegah masuknya antimikroba ke dalam sel. Menurut Tommassen (2010), lapisan outer membrane bakteri Gram negatif yang tersusun dari gliserofosfolipida dan lipopolisakarida berfungsi sebagai permeability barrier yang melindungi sel dari senyawa-senyawa yang berbahaya seperti zat-zat antimikroba yang berasal dari lingkungan. Bakteri P. aeruginosa ATCC27853 juga dilaporkan resisten terhadap antibiotik (Iliev et al., 2015). Ketahanan bakteri ini terhadap senyawa antimikroba atau antibiotik penisilin 10\% diduga disebabkan oleh kemampuan bakteri ini memompa senyawa antimikroba atau antibiotik keluar sel melalui sistem multidrug efflux pump (ARDB, 2009).

\section{Konsentrasi Penghambatan Minimum (KHM)}

KHM adalah konsentrasi terendah yang dapat menghambat pertumbuhan bakteri dalam suatu medium. Hasil menunjukkan bahwa KHM ekstrak etanol kulit kayu akway terhadap bakteri B. cereus dan S. aureus masing masing adalah 9,9 dan 8,9 mg/ml (Tabel 2).

Tabel 2. Konsentrasi Hambat Minimum ekstrak etanol kulit kayu akway

\begin{tabular}{lcl}
\hline \multicolumn{1}{c}{ Bakteri Uji } & $\begin{array}{c}\mathrm{KHM} \\
(\mathrm{mg} / \mathrm{ml})\end{array}$ & Persamaan Regresi linear \\
\hline B. cereus & 9,9 & $\mathrm{Y}=78,94 \mathrm{x}-108,63, \mathrm{R}^{2}=0,82$ \\
S. aureus & 8,9 & $\mathrm{Y}=100,17 \mathrm{x}-127,87, \mathrm{R}^{2}=0,93$ \\
\hline
\end{tabular}

Tabel 2. menunjukkan bahwa konsentrasi ekstrak etanol minimum sebesar $8,9 \mathrm{mg} / \mathrm{ml}$ dapat menghambat pertumbuhan bakteri $S$. aureus sedangkan untuk bakteri $B$. cereus diperlukan konsentrasi minimum sebesar $9,9 \mathrm{mg} / \mathrm{ml}$. Nilai KHM ekstrak akway tersebut lebih tinggi dibandingkan ekstrak etanol daun Quercus infectoria, Phragmanthera capitata dan lebih rendah dibandingkan ekstrak etanol Panax ginseng terhadap bakteri B. cereus dan S. aureus. KHM ekstrak etanol daun Quercus infectoria terhadap B. cereus dan S. aureus masing-masing sebesar 0,5 mg/ml (Shariatifar et al., 2014), ekstrak etanol daun Phragmanthera capitata masing-masing sebesar 2,5 dan $5 \mathrm{mg} / \mathrm{ml}$ (Ohikhena et al., 2017), sedangkan KHM ekstrak etanol Panax ginseng terhadap B. cereus dan S. aureus masing-masing sebesar 12,5 dan $50 \mathrm{mg} / \mathrm{ml}$ (Na et al., 2018).

Hasil dalam Tabel 2. juga menunjukkan bahwa bakteri B. cereus bersifat lebih tahan terhadap ekstrak etanol kulit kayu akway dibandingkan $S$. aureus. Perbedaan ketahanan bakteri terhadap ekstrak etanol kulit kayu akway diduga disebabkan oleh perbedaan sensitivitas bakteri terhadap senyawa antimikroba dalam ekstrak etanol kulit kayu akway. Sensitivitas bakteri 
terhadap senyawa antimikroba berbeda-beda diantara masing-masing galur bakteri (Seow et al., 2014).

\section{Aktivitas Antimikroba Ekstrak pada Pemanasan $100^{\circ} \mathrm{C}$}

Pengujian pengaruh pemanasan ekstrak etanol kulit kayu akway terhadap daya antimikrobanya dilakukan pada suhu $100^{\circ} \mathrm{C}$ selama 0-25 menit. Pengujian ini bertujuan untuk mengetahui ketahanan panas senyawa antimikroba yang terdapat dalam ekstrak. Hasil analisis varian menunjukkan bahwa pemanasan ekstrak pada suhu $100^{\circ} \mathrm{C}$ selama $0-25$ menit tidak berpengaruh nyata terhadap kapasitas antimikroba ekstrak etanol kulit kayu akway (Tabel 3.).

Tabel 3. Pengaruh pemanasan terhadap daya hambat ekstrak etanol

\begin{tabular}{ccc}
\multicolumn{3}{c}{ kulit kayu akway } \\
\hline Pemanasan pada & \multicolumn{2}{c}{ Daya Hambat Rataan $(\mathrm{mm})$} \\
\cline { 2 - 3 } $100^{\circ} \mathrm{C}$ (menit) & B. Cereus & S. aureus \\
\hline 0 & $13,70 \pm 0,22$ & $13,73 \pm 1,02$ \\
5 & $13,88 \pm 0,60$ & $13,60 \pm 1,20$ \\
10 & $13,43 \pm 0,53$ & $13,30 \pm 0,78$ \\
15 & $13,75 \pm 0,35$ & $13,28 \pm 0,67$ \\
20 & $14,15 \pm 0,92$ & $13,73 \pm 0,39$ \\
25 & $13,93 \pm 0,95$ & $14,50 \pm 0,71$ \\
\hline
\end{tabular}

Perlakuan pemanasan ekstrak etanol kulit kayu akway yang tidak berpengaruh nyata terhadap aktivitas antimikrobanya menunjukkan bahwa senyawa antimikroba yang terdapat dalam ekstrak etanol kulit kayu akway stabil terhadap pemanasan pada suhu $100^{\circ} \mathrm{C}$ dengan waktu pemanasan sampai 25 menit. Hasil yang sama dilaporkan pada ekstrak etanol Coriandrum sativum dan Panax ginseng dimana perlakuan pemanasan tidak berpengaruh nyata terhadap aktivitas antimikroba ekstrak (Cao et al., 2012; Na et al., 2018).

\section{Aktivitas Antimikroba Ekstrak pada Beberapa Tingkat Keasaman (pH)}

Pengujian pengaruh tingkat keasaman ekstrak etanol terhadap aktivitas antimikrobanya dilakukan pada $\mathrm{pH}$ 4-8,5. Pengujian ini dilakukan untuk mengetahui pengaruh $\mathrm{pH}$ terhadap stabilitas senyawa antimikroba dalam ekstrak. Hasil pengujian menunjukkan bahwa pH tidak berpengaruh nyata terhadap aktivitas antimikroba ekstrak etanol kulit kayu akway. Daya hambat ekstrak etanol kulit kayu akway pada $\mathrm{pH}$ 4-8,5 terhadap B. cereus dan S. aureus masingmasing-masing sebesar 9,85-12,30 mm dan 10,00-10,05 mm (Tabel 4.).

Tabel 4. menunjukkan bahwa senyawa antibakteri ekstrak etanol kulit kayu akway stabil terhadap perlakuan $\mathrm{pH}$ 4-8,5. Namun demikian terdapat kecenderungan peningkatan daya hambat ekstrak etanol kulit kayu akway dengan menurunnya $\mathrm{pH}$ pada bakteri $B$. cereus. Hal ini menunjukkan bahwa bakteri $B$. cereus lebih rentan terhadap perubahan $\mathrm{pH}$ dibandingkan dengan $S$. aureus. Kerentanan B. cereus terhadap perubahan $\mathrm{pH}$ diduga karena rentang $\mathrm{pH}$ pertumbuhan bakteri ini lebih sempit dibandingkan $S$. aureus. Batt (2000) melaporkan bahwa rentang $\mathrm{pH}$ pertumbuhan $B$. cereus adalah $\mathrm{pH}$ 4,9-9,3 sedangkan $S$. aureus memiliki $\mathrm{pH}$ pertumbuhan 4,0-9,8 (Jay et al., 2005). 
Tabel 4. Daya hambat ekstrak etanol kulit kayu akway pada beberapa tingkat keasaman $(\mathrm{pH})$

\begin{tabular}{ccc}
\hline \multirow{2}{*}{$\begin{array}{c}\text { Keasaman Ekstrak } \\
(\mathrm{pH})\end{array}$} & \multicolumn{2}{c}{ Daya Hambat Rataan $(\mathrm{mm})$} \\
\cline { 2 - 3 } & B. Cereus & S. aureus \\
\hline 4 & $12,30 \pm 0,00$ & $10,00 \pm 0,00$ \\
5 & $11,00 \pm 0,00$ & $10,05 \pm 0,00$ \\
6 & $10,78 \pm 0,32$ & $10,00 \pm 0,00$ \\
7 & $10,38 \pm 0,17$ & $10,03 \pm 0,04$ \\
8,5 & $9,85 \pm 0,28$ & $10,05 \pm 0,07$ \\
\hline
\end{tabular}

\section{Aktivitas Antimikroba Ekstrak pada Beberapa Konsentrasi Garam}

Pengujian aktivitas antimikroba ekstrak etanol pada beberapa tingkat konsentrasi garam $\mathrm{NaCl}$ dilakukan pada konsentrasi $0-5 \%$. Pengujian ini bertujuan untuk mengetahui pengaruh garam terhadap daya antimikroba ekstrak etanol kulit kayu akway. Hasil menunjukkan perlakuan konsentrasi garam sampai dengan 5\% tidak menunjukkan pengaruh yang nyata terhadap kapasitas antimikroba ekstrak etanol kulit kayu akway terhadap B. cereus dan S. aureus (Tabel 5.).

Tabel 5. Pengaruh garam terhadap daya hambat ekstrak etanol

\begin{tabular}{ccc}
\multicolumn{3}{c}{ kulit kayu akway } \\
\hline Konsentrasi Garam & \multicolumn{2}{c}{ Daya Hambat Rataan $(\mathrm{mm})$} \\
\cline { 2 - 3 }$(\%)$ & B. Cereus & S. aureus \\
\hline 0 & $10,05 \pm 0,00$ & $10,10 \pm 0,00$ \\
1 & $10,59 \pm 0,02$ & $10,41 \pm 0,02$ \\
2 & $10,54 \pm 0,02$ & $10,39 \pm 0,02$ \\
3 & $10,46 \pm 0,19$ & $10,40 \pm 0,00$ \\
4 & $10,44 \pm 0,30$ & $10,39 \pm 0,002$ \\
5 & $9,78 \pm 0,04$ & $10,40 \pm 0,07$ \\
\hline
\end{tabular}

Daya hambat ekstrak etanol kulit kayu akway terhadap B. cereus dan S. aureus pada konsentrasi garam 0-5\% masing-masing adalah 10,05-10,59 mm dan 10,10-10,40 mm. Hasil tersebut menunjukkan bahwa konsentrasi garam 5\% cenderung tidak dapat meningkatkan kapasitas antimikroba ekstrak etanol kulit kayu akway. Hal tersebut diduga disebabkan konsentrasi garam 5\% tidak menghambat pertumbuhan B. cereus dan S. aureus. Tsai et al. (2011) melaporkan bahwa bakteri S. aureus dapat tumbuh pada konsentrasi garam $\mathrm{NaCl}$ sampai 15\% sedangkan B. cereus dapat tumbuh pada konsentrsi garam sebesar 5\% (Patra \& Baek, 2016).

\section{KESIMPULAN}

Ekstrak etanol kulit kayu akway merupakan ekstrak yang memiliki aktivitas antibakteri spektrum sempit karena secara selektif menghambat pertumbuhan bakteri Gram positif. Konsentrasi hambat minimum ekstrak etanol kulit kayu akway terhadap Bacillus cereus dan Staphylococcus aureus masing-masing 9,9 dan $8,9 \mathrm{mg} / \mathrm{ml}$. Lama pemanasan ekstrak pada $100^{\circ} \mathrm{C}$ selama 25 menit, tingkat keasaman (pH 4-8,5) dan konsentrasi garam $\mathrm{NaCl} 5 \%$ tidak berpengaruh nyata terhadap stabilitas antibakteri ekstrak etanol kulit kayu akway. 


\section{UCAPAN TERIMA KASIH}

Pada kesempatan ini penulis menyampaikan terima kasih kepada Kementerian Riset, Teknologi dan Pendidikan Tinggi yang telah memberikan dana untuk pelaksanaan penelitian ini dan kepada Kepala Laboratorium Teknologi Pertanian Fakultas Teknologi Pertanian Universitas Papua yang telah memfasilitasi pelaksanaan penelitian ini.

\section{DAFTAR PUSTAKA}

ARDB. (2009). Antibiotic Resistance Data Base: Pseudomonas aeruginosa. Center for Bioinformatic and Computational: Biology University of Maryland college Park MD20742.

Balouiri, M., Sadiki, M., \& Ibnsouda, S.K. (2016). Methods for In Vitro Evaluating Antimicrobial Activity: a Review. Journal of Pharmaceutical Analysis, 6(2):71-79. http://doi.org/ 10.1016/j.jpha.2015.11.005.

Batt, C. (2000). Bacillus cereus. in R. B. Robinson, C. A. Batt \& P. D. Patel, Encyclopedia of Food Microbiology (pp. 119-124). London: Academic Press.

Bloomfield, S. (1991). Methods for Assesing Antimicrobial Activity. in S. P. Denyer \& H. B. Hugo, Mechanism of Action of Chemical Biocides Their Study and Exploitation (pp. 1-22). London: Scientific Publication.

Cao, X. Z., You. J. M., Lin. X. S., \& Zhang, Y. L. (2012). Antimicrobial Activity of The Extracts from Coriandrum sativum. International Journal of Food Nutrition and Safety, 1(2), 54-59.

Cepeda, G. N., Hariyadi, R. D., \& Supar. (2012). Penghambatan Ekstrak Etanol Sereh (Cymbopogon citratus (DC) Stapf.) terhadap Produksi Verotoksin Escherichia coli Verotoksigenik. Jurnal Natur Indonesia, 13(1), 72-76. https://doi.org/10.31258/jni.13.01.\%p.

Cepeda, G. N., Santoso, B. B., Lisangan, M. M., \& Silamba, I. (2011a). Komposisi Kimia Minyak Atsiri Kulit Kayu Akway (Drimys piperita Hook.f.). Bionatura, 13(2), 118-124.

Cepeda, G. N., Santoso, B. B., Lisangan, M. M., \& Silamba, I. (2011b). Komposisi Kimia Minyak Atsiri Daun Akway. Makara Sains, 15(1), 63-66. https://doi.org/10.7454/mss.v15i1.880.

Cepeda, G. N., Santoso, B. B., Lisangan, M. M., \& Silamba, I. (2010). Penapisan Fitokimia Akway. Jurnal Agrotek, 1(8), 28-33.

Da Silva, A. C., Lopes, P. M., De Azevedo, M. M., Costa, D. C., Alviano, C. S., \& Alviano, D. S. (2012). Biological Activities of $\alpha$-pinene and $\beta$-pinene Enantiomer. Molecules, 17, 6305-6316. https://doi.org/10.3390/molecules17066305.

Ginovyan, M. M. (2017). Effect of Heat Treatment on Antimicrobial Activity of Crude Extracts of Some Armenian Herbs. Chemistry and Biology, 51(2), 113-117.

Grace, U. S., Sankari, M., \& Gopi. (2017). Antimicrobial Activity of Ethanolis Extract Zingiber officinale an In Vitro Study. Journal of Pharmaceutical Sciences and Research, 9(9), 1417-1419.

Iliev, I., Marhova, M., Gochev, V., Tsankova, M., \& Trifonova, S. (2015). Antibiotic Resistance of Gram Negative Benthic Isolated from the Sediments of Kardzhali Dam (Bulgaria). Biotechnology \& Biotechnological Equipment, 29(2), 274-280. https://doi.org/ 10.1080/13102811.2014.998160.

Jay, J. M., Loessner, M. J., \& Goleden, D. A. (2015). Modern Food Microbiology 7th edition (pp. 545-560). USA: Springer.

Mardiana, R. N., \& Handayani, N. (2016). Uji Aktivitas Antibakteri Ekstrak Daun Sambiloto (Andrographis paniculata) terhadap Bacillus cereus dan Pseudomonas aeruginosa. Biofarmasi, 14 (1), 19-24. https://doi.org/10.13057/biofar/f140103.

Na, S., Kim, J. H., Rhee, Y. K., \& Oh, S. W. (2018). Enhancing the Antimicrobial Activity of Ginseng Against Bacillus cereus and Staphylococcus aureus by Heat Treatment. Food Science and Biotechnology, 27(1), 203-210. https://doi.org/10.1007/s10068-017-0209-9.

Naufalin, R., \& Rukmini, H. S. (2018). Antibacterial Activity of Kecombrang Flower Extract (Nicolaia speciosa) Microencapsulation with Food Additive Materials Formulation. IOP Conference. 
Series: Earth and Environmental Science 102 (2018) 012035. https://doi :10.1088/1755$1315 / 102 / 1 / 012035$

Ohikhena, F. U., Wintola, O. A., \& Afolayan, A. J. (2017). Evaluation of the Antibacterial and Antifungal Properties of Phragmanthera capitata (Sprengel) Balle (Loranthaceae), a Mistletoe Growing on Rubber Tree, Using the Dilution Techniques. The Scientific World Journal, 2017, 1-8. https://doi.org/10.1155/2017/9658598.

Patra, J. K., \& Baek, K. H. (2016). Antibacterial Activity and Action Mechanism of the Essential Oil from Enteromorpha linza L. Against Foodborne Pathogenic Bacteria. Molecules, 21(3), 388. https://doi.org/10.3390/molecules21030388.

Qiao, H., \& Sun, T. J. (2014). Antibacterial Activity of Ethanol Extract and Fractions Obtained from Taraxacum mongolicum Flower. Resource Journal of Pharmacognosy, 1(4), 35-39.

Romasi, E. F., Karina, J., \& Parhusip, A. J. N. (2011). Antibacterial Activity of Papaya Leaf Extracts against Pathogenic Bacteria. Makara Seri Teknologi, 15(2), 173-177.

Seow, Y. X., Yeo, C. R., Chung, H. L., \& Yuk, H.-G. (2014). Plant Essential Oils as Active Antimicrobial Agents. Critical Reviews in Food Science and Nutrition, 54, 625-644. https://doi.org/ 10.1080/10408398.2011.599504.

Shariatifar, N., Fathabad, A. E., Khaniki, G. J., \& Nasrabadi, H. G. (2014). Evaluation of the Antibacterial Activity of Essential Oil and Aqueous and Ethanolic Extracts of Quercus infectoria Leaves on Food-Borne Pathogenic Bacteria. International Journal of Pharma Sciences and Research, 5 (10), 709-713.

Singh, N., Gupta, S., \& Rathore, V. (2017). Comparative Antimicrobial Study of Ethanolic Extract of Leaf and Rhizome of Curcuma longa Linn. Pharmacognosy Journal, 9(2), 208-212. https://doi.org/10.5530/pj.2017.2.35.

Stevens, P. F. (2017, July 4). http://www.mobot.org/MOBOT/research/APweb/July 4, 2017. Retrieved Maret 2, 2019, from Canellales. Angiosperm Phylogeny Website: http://www.mobot.org

Syakir, M., Bermawie, N., Agusta, H., \& Paysei, E. N. (2011). Karakterisasi Sifat Mormologi dan Penyebaran Kayu Akway (Drimys sp.) di Papua Barat. Jurnal Penelitian Tanaman Industri, 17(4), 169-173. https://doi.org/10.21082/littri.v17n4.2011.163\%20-\%20168.

Tommasen, J. (2010). Assembly of Outer-Membrane Proteins in Bacteria and Mitochondria. Microbiology, 156, 2587-2596. https://doi.org/10.1099/mic.0.042689-0.

Tsai, M., Ohniwa, R. L., Kato, Y., Takeshita, S. L., Ohta, T., Saito, S., et al. (2011). Staphylococcus Requires Cardiolipin for Survival Under Condition of High Salinity. BMC. Microbiology, 11(13), 1-12. https://doi.org/10.1186/1471-2180-11-13.

Valle Jr, D. L., Andrade, J. I., Puzon, J. J., Cabrera, E. C., \& Rivera, W. L. (2015). Antibacterial Activities of Ethanol Extracts of Philippine Medicinal Plants against Multidrug-Resistant Bacteria. Asian Pasific Journal of Tropical Biomedicine, 5(7), 532-540. https://doi.org/ 10.1016/j.apjtp.2015.04.005.

Wang, W., Li, N., Luo, M., Zu, Y., \& Efferth, T. (2012). Antibacterial Activity and Anticancer Activity of Rosmarinus officinalis L. Essential Oil Compared to that of Its Main Components. Molecules, 17, 2704-2713. https://doi.org/10.3390/molecules17032704. 